\title{
In Vitro and In Vivo Biochemical Evaluations of the Methanolic Leaf Extract of Garcinia kola
}

\author{
Jelili A. Badmus, ${ }^{1,2}$ Olaniyi T. Adedosu, ${ }^{1}$ Emmanuel G. Adeleke, ${ }^{1}$ Kehinde H. Akinboro, ${ }^{1}$ \\ Bayonle I. Odeyemi, ${ }^{1}$ Bolanle I. Ayoola, ${ }^{1}$ and Donavon C. Hiss ${ }^{2}$ \\ ${ }^{1}$ Department of Biochemistry, Ladoke Akintola University of Technology, PMB 4000, Ogbomosho 210211, Nigeria \\ ${ }^{2}$ Department of Medical Biosciences, University of the Western Cape, Private Bag X17, Bellville 7535, South Africa
}

Correspondence should be addressed to Jelili A. Badmus; jabadmus@lautech.edu.ng

Received 27 May 2014; Accepted 3 September 2014; Published 30 October 2014

Academic Editor: Graziella Vecchio

Copyright (C) 2014 Jelili A. Badmus et al. This is an open access article distributed under the Creative Commons Attribution License, which permits unrestricted use, distribution, and reproduction in any medium, provided the original work is properly cited.

\begin{abstract}
Garcinia kola Heckel (Guttiferae) leaves have received limited scientific attention despite their traditionally acclaimed medicinal properties. The scavenging ability of the methanolic leaf extract (MLE) of G. kola was assayed for hydroxyl radical $\left(\mathrm{OH}^{*}\right)$, superoxide anion $\left(\mathrm{O}_{2}^{-}\right)$, 1,1-diphenyl-2-picrylhydrazyl (DPPH), azinobis-3-ethyl-benzothiazoline-6-sulfonic acid $\left(\mathrm{ABTS}^{\circ+}\right)$, and lipid peroxidation (LP) activity in egg yolk, rat liver, and brain homogenates. Total phenolic and flavonoid contents of the extract were also evaluated. Group I animals were given oral doses of water, whereas Group II and Group III animals received 100 and $200 \mathrm{mg} / \mathrm{kg}$ body weight (bw) MLE, respectively, for 14 days. Plasma glucose, magnesium, $\gamma$-glutamyltransferase (GGT/ $\gamma$ GT), alanine aminotransferase (ALT), aspartate aminotransferase (AST), creatinine, and urea were evaluated. Hepatic reduced glutathione (GSH), glutathione peroxidase (GPx), superoxide dismutase (SOD), LP, and liver histopathological appearance were also assessed. The extract scavenged $\mathrm{OH}^{*}, \mathrm{O}_{2}{ }^{-}, \mathrm{DPPH}$, and $\mathrm{ABTS}^{\circ+}$ and inhibited LP in egg yolk, rat liver, and brain homogenates. Furthermore, oral administration of the extract showed no adverse effects on hepatic and renal function tests. Increased hepatic GSH and nonsignificant changes in LP, GPx and SOD activities, and liver histology were observed. These results suggest that G. kola leaves have antioxidant activities which may have application in traditional medicine.
\end{abstract}

\section{Introduction}

Medicinal plants have been used as folklore remedies over the years to treat and manage human ailments. A large body of scientific evidence has been collated to show their immense potential in various traditional cultures [1]. They contain a large variety of chemical substances that possess important therapeutic properties used in the treatment of innumerable diseases [2]. These chemical substances generally occur as secondary plant metabolites, including saponins, tannins, essential oils, flavonoids, and alkaloids [3]. The medicinal potential of natural plant products has led to growing research into the discovery of novel drugs as alternatives to synthetic ones whose beneficial effects are often eclipsed by severe toxicities and adverse events.

Garcinia kola, a medium-sized tree found in most forests, belongs to the family Guittiferae and is commonly referred to as bitter kola. G. kola has been popularized as a "wonder plant" among South Western Nigerians because every part of it has been found to be of some medicinal value [4]. G. kola is commonly used in folklore remedies for the treatment of ailments such as liver disorders, hepatitis, diarrhoea, laryngitis, bronchitis, and gonorrhoea [5]. It contains a complex mixture of biflavonoids, prenylated benzophenones, and xanthones [6]. Garcinia biflavanones (GB1 and GB2) (Figure 1) and kola flavanones are the major components of G. kola [7]. The therapeutic potential of G. kola seeds has been widely reported, including hepatoprotective effects [8] and treatment of cirrhosis and hepatitis $[9,10]$. Even though the seeds and leaves of the plant enjoy considerable importance in folk medicine, to our knowledge, there is scant scientific information on the leaf of the plant compared to the seed, despite being called "wonder plant." In our continuing efforts to isolate a potential natural proactive agent for the treatment of oxidative related diseases without attendant toxicity, this study, however, sought to evaluate the in vitro antioxidant 
<smiles></smiles>

FIgURE 1: The structure of the Garcinia biflavonoids (for GB1, $\mathrm{R}$ is $\mathrm{H}$; GB2, R is OH) GB1 (3,4,4,5, 5,7,7-heptahydroxy-3,8-biflavanone) and GB2 (3,4,4,5, 5,5,7,7-hexahydroxy-3,8-biflavanone).

potential of the MLE of the leaf of the plant and its in vivo effects in male albino rats.

\section{Materials and Methods}

2.1. Chemicals. Trichloroacetic acid (TCA), ferrous sulphate $\left(\mathrm{FeSO}_{4}\right)$, thiobarbituric acid (TBA), sodium dodecyl sulfate (SDS), Folin-Ciocalteu reagent, glacial acetic acid, potassium ferricyanide, quercetin, gallic acid, ascorbic acid, azinobis-3-ethyl-benzothiazoline-6-sulfonic acid $\left(\mathrm{ABTS}^{+}\right)$, and 1,1-diphenyl-2-picrylhydrazyl (DPPH) were procured from Sigma Co. (St. Louis, MO) USA. All other reagents used were of analytical grade.

2.2. Experimental Animals. All experiments involving rats were performed in accordance with prescribed ethics of animal use and investigator obligations (Guide for the Care and Use of Laboratory Animals 8th edition, 2011, Institute for Laboratory Animal Research, National Research Council, Washington, DC: National Academy Press; http://www.nap.edu). Rats weighing between 180 and $200 \mathrm{~g}$ were used for this investigation. The animals were fed with rat chow pellets and water ad libitum and maintained under a $12 \mathrm{~h}$ light and $12 \mathrm{~h}$ dark photo cycle throughout the period of the experiment.

2.3. Plant Material. Fresh G. kola leaves were collected from the land surrounding the College of Health Sciences, LAUTECH, Ogbomosho, Oyo State, Nigeria, and were authenticated by Dr. A. T. J. Ogunkunle, Department of Pure and Applied Biology, of the same institution.

2.4. Extraction Procedure. The powdered leaves of G. kola (1 kg) were exhaustively extracted with $3000 \mathrm{~mL}$ of $70 \%$ methanol. Methanolic leaf extract (MLE) was concentrated using a rotary evaporator. The percentage yield of the extract was calculated as

$$
\frac{\text { Dry weight of the extract }}{\text { Powdered leaves }(1 \mathrm{~kg})} \times 100 \text {. }
$$

2.5. Experimental Protocol. Rats for this study were randomized into three groups of six rats each. Groups I, II, and III were given distilled water and extract $100 \mathrm{mg} / \mathrm{kg}$ and $200 \mathrm{mg} / \mathrm{kg}$ body weight, respectively, through oral gavage for 14 consecutive days. All the animals were sacrificed by cervical dislocation $24 \mathrm{hr}$ after the last exposure to the MLE of G. kola. Blood was obtained through heart puncture and collected into heparinized tubes and the livers of the rats were also removed. A small portion of the liver was fixed in $10 \%$ formalin for histological examination. The remaining part of the liver was washed in $1.15 \% \mathrm{KCl}$ and blotted dry. Rat liver homogenates were prepared in potassium phosphate buffer $(10 \mathrm{mM}, \mathrm{pH} 7.4 ; 1: 4 \mathrm{w} / \mathrm{v})$ using a homogenizer fitted with a Teflon pestle. The homogenates were centrifuged at 9,000 $\mathrm{g}$ for $10 \mathrm{~min}$ to obtain the postmitochondrial fraction (PMF) which was used to evaluate reduced glutathione (GSH), superoxide dismutase (SOD), glutathione peroxidase (GPx), and lipid peroxidation.

2.6. In Vitro Antioxidant Assay. The hydroxyl radical scavenging capacity of the MLE was evaluated according to an established method of Halliwell and Grootveld [11]. Superoxide anion scavenging ability, DPPH and ABTS were determined according to the methods of Beauchamp and Fridovich [12], Mensor et al. [13] and Re et al. [14] respectively. Inhibition of lipid peroxidation in egg yolk, rat liver, and brain homogenates as described by Ruberto et al. [15] was followed whereas total phenol and flavonoids were estimated by the methods of McDonald et al. [16] and Zhishen et al. [17], respectively.

2.7. In Vivo Study. The manual methods described by Cheesbrough [18] were used to evaluate hematological constituents. The concentrations of plasma glucose, magnesium, urea, creatinine, $\gamma \mathrm{GT}$, ALT, and AST were determined with kits from Chemelex, S.A. 08420 Canovelles, Barcelona (Spain). Activities of rat hepatic GSH, SOD, and GPx were determined as previously described [19], Misra and Fridovich [20] and Rotruck et al. [21], respectively, while lipid peroxidation was detected as thiobarbituric acid reactive species and calculated as malondialdehyde (MDA) as described earlier [22].

2.8. Statistical Analysis. Data are expressed as mean \pm standard deviation (SD) from the 6 rats in each group. The results were analysed statistically using one-way analysis of variance (ANOVA) followed by Dunnett's test. The minimum level of significance was fixed at $P<0.05$. The $50 \%$ inhibitory concentration $\left(\mathrm{IC}_{50}\right)$ of MLEs was estimated from regression analysis of concentration-inhibition curves using GraphPad Prism version 5.02 statistical software (GraphPad Software, San Diego California USA, http://www.graphpad.com). In this study, the $\mathrm{IC}_{50}$ value is defined as the concentration of 
extract required to scavenge 50\% free radicals and is inversely proportional to the activity of the extract.

\section{Results}

3.1. Percentage Extract Yield. The weight of the dried methanolic leaf extract obtained was $223.5 \mathrm{~g}$. The percentage yield of the extract was $22.35 \%$.

\subsection{Hydroxyl Radical, Superoxide Anion, DPPH, and ABTS ${ }^{\circ+}$} Scavenging Activities. The MLE of G. kola showed inhibition of hydroxyl radical scavenging activity with an $\mathrm{IC}_{50}$ value of $748.0 \mu \mathrm{g} / \mathrm{mL}$ compared with an $\mathrm{IC}_{50}$ value of $45.2 \mu \mathrm{g} / \mathrm{mL}$ for quercetin (Table 1). The extract scavenged superoxide anion with an $\mathrm{IC}_{50}$ of $10.0 \mu \mathrm{g} / \mathrm{mL}$, compared to ascorbic acid $\mathrm{IC}_{50}$ of $2.3 \mu \mathrm{g} / \mathrm{mL}$ (Table 2). The MLE of G. kola exhibited DPPH scavenging activity with $\mathrm{IC}_{50}$ value of $126.0 \mu \mathrm{g} / \mathrm{mL}$ while ascorbic acid yielded an $\mathrm{IC}_{50}$ value of $5.4 \mu \mathrm{g} / \mathrm{mL}$ (Table 3 ). ABTS $^{\circ+}$ was inhibited by the extract in a dose-dependent manner with an $\mathrm{IC}_{50}$ value of $34.3 \mu \mathrm{g} / \mathrm{mL}$ while ascorbic acid showed an $\mathrm{IC}_{50}$ value of $5.7 \mu \mathrm{g} / \mathrm{mL}$ (Table 4).

3.3. Inhibition of In Vitro Lipid Peroxidation in Egg Yolk, Rat Liver, and Brain. Table 5 shows that the MLE of G. kola inhibited lipid peroxidation in the egg yolk with an $\mathrm{IC}_{50}$ value of $190.0 \mu \mathrm{g} / \mathrm{mL}$ while the $\mathrm{IC}_{50}$ value for ascorbic acid was $52.2 \mu \mathrm{g} / \mathrm{mL}$. The extract inhibited lipid peroxidation induced by $\mathrm{FeSO}_{4}$ in rat liver homogenate in a concentrationdependent manner (Table 6). The $\mathrm{IC}_{50}$ value of inhibition of lipid peroxidation by the extract was $218.0 \mu \mathrm{g} / \mathrm{mL}$ while ascorbic acid (the standard) produced an $\mathrm{IC}_{50}$ value of $40.6 \mu \mathrm{g} / \mathrm{mL}$. $\mathrm{FeSO}_{4}$-induced lipid peroxidation in rat brain homogenate was similarly inhibited by the extract in a dosedependent manner as shown in Table 7 with an $\mathrm{IC}_{50}$ value of $228.0 \mu \mathrm{g} / \mathrm{mL}$ while ascorbic acid showed $\mathrm{IC}_{50}$ value of $36.5 \mu \mathrm{g} / \mathrm{mL}$.

3.4. Total Phenol and Flavonoid Contents. Total flavonoid content of the MLE of G. kola expressed as $\mu \mathrm{g} / \mathrm{mg}$ quercetin equivalent was 0.902 while total phenol content expressed as $\mu \mathrm{g} / \mathrm{mg}$ gallic acid equivalent was 1.196 .

3.5. Hematological Analysis. Hematological parameters are shown in Table 8 . The hematological results show that the extract did not induce significant changes in the hematological parameters evaluated. The extract at $100 \mathrm{mg} / \mathrm{kg}$ induced increase in the white blood cell count (WBC) and reduction was observed in hemoglobin $(\mathrm{Hb})$. These changes were, however, not significant when compared with other groups.

3.6. Biochemical Analysis. Biochemical parameters are presented in Table 9. The plant extract did not have significant effects on some of biochemical parameters evaluated. However, insignificant $(P<0.05)$ decreases in plasma creatinine and magnesium occurred while a significant $(P<$ 0.01 ) decrease in plasma glucose at $200 \mathrm{mg} / \mathrm{kg}$ extract was observed.

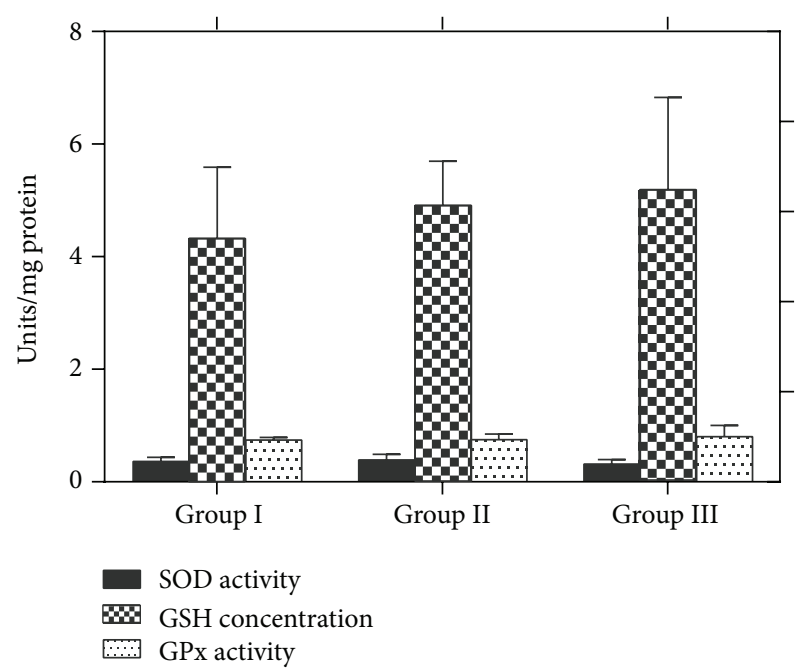

FIGURE 2: Hepatic GSH concentration and SOD and GPx activities in liver homogenates prepared from rats treated with distilled water as control (Group I), $100 \mathrm{mg} / \mathrm{kg}$ (Group II) or $200 \mathrm{mg} / \mathrm{kg}$ (Group III) MLE of G. kola. Data are presented as means \pm SD $(n=6)$.

3.7. Effect of the Extract on Rat Hepatic GSH Levels. Administration of the extract to rats caused an increase in GSH levels compared to the control group (Figure 2). The percentage increase in GSH concentration of $100 \mathrm{mg} / \mathrm{kg}$ and $200 \mathrm{mg} / \mathrm{kg}$ extract was $13.7 \%$ and $20.1 \%$, respectively (Figure 2).

3.8. Effect of the Extract on Rat Hepatic SOD and GPx Activities and Lipid Peroxidation. The extract at both doses $(100 \mathrm{mg} / \mathrm{kg}$ and $200 \mathrm{mg} / \mathrm{kg}$ ) did not induce significant changes in hepatic SOD activities compared with the control group. However, the extract at 100 and $200 \mathrm{mg} / \mathrm{kg}$ showed significant $(P<$ 0.05 ) increases in the activity of GPx by $1.08 \%$ and $7.83 \%$, respectively, compared with the control group (Figure 2). The extract did not cause any increase in thiobarbituric reactive oxygen species as measured by malondialdehyde, a marker of lipid peroxidation (Figure 3 ). The results of histopathological analysis of liver sections prepared from rats in each treatment group are depicted in Figure 4. The MLE did not adversely affect the liver tissues as evidenced by well-preserved hepatocytes, nonvacuolated cytoplasm, welldemarcated sinusoids, no area of necrosis, and no fatty degeneration.

\section{Discussion}

Hydroxyl radicals are known to damage cell membrane through initiation of peroxidation of its lipid components [23]. Hydroxyl radicals are produced by the reaction of ferric $\left(\mathrm{Fe}^{3+}\right)$-EDTA, $\mathrm{H}_{2} \mathrm{O}_{2}$, ascorbic acid, and deoxyribose. The extent of inhibition of deoxyribose degradation in the presence of an agent gives an indication of hydroxyl radical scavenging ability. The MLE of G. kola exhibited dosedependent inhibition of hydroxyl radical formation (Table 1). This result suggests that the extract has the potential to 
TABLE 1: Hydroxyl radical scavenging activity of the methanolic extract of Garcinia kola and quercetin.

\begin{tabular}{|c|c|c|c|c|}
\hline Sample & Concentration $(\mu \mathrm{g} / \mathrm{mL})$ & $\%$ Inhibition $(n=6)$ & $\mathrm{IC}_{50}(\mu \mathrm{g} / \mathrm{mL})$ & Regression equation \\
\hline \multirow{4}{*}{ Garcinia kola } & 400.0 & $44.30 \pm 0.01$ & \multirow{4}{*}{748.0} & \multirow{4}{*}{$y=0.0144 x+39.21\left(r^{2}=0.943\right)$} \\
\hline & 500.0 & $47.10 \pm 0.08$ & & \\
\hline & 600.0 & $48.10 \pm 0.05$ & & \\
\hline & 800.0 & $50.40 \pm 0.04$ & & \\
\hline \multirow{5}{*}{ Quercetin } & 10.0 & $18.20 \pm 0.10$ & \multirow{5}{*}{45.2} & \multirow{5}{*}{$y=0.752 x+7.34\left(r^{2}=0.806\right)$} \\
\hline & 20.0 & $23.00 \pm 0.03$ & & \\
\hline & 30.0 & $26.00 \pm 0.40$ & & \\
\hline & 40.0 & $30.00 \pm 0.01$ & & \\
\hline & 50.0 & $52.30 \pm 0.02$ & & \\
\hline
\end{tabular}

Results are expressed as means \pm SD of five parallel measurements.

TABLE 2: Superoxide anion scavenging activity of the methanolic extract of Garcinia kola and ascorbic acid.

\begin{tabular}{|c|c|c|c|c|}
\hline Sample & Concentration $(\mu \mathrm{g} / \mathrm{mL})$ & $\%$ Inhibition $(n=6)$ & $\mathrm{IC}_{50}(\mu \mathrm{g} / \mathrm{mL})$ & Regression equation \\
\hline \multirow{5}{*}{ Garcinia kola } & 3.30 & $26.50 \pm 0.16$ & \multirow{5}{*}{10.0} & \multirow{5}{*}{$y=3.30 x+17.1\left(r^{2}=0.960\right)$} \\
\hline & 6.70 & $42.70 \pm 0.12$ & & \\
\hline & 10.00 & $50.50 \pm 0.10$ & & \\
\hline & 13.30 & $55.70 \pm 0.02$ & & \\
\hline & 16.70 & $75.10 \pm 0.07$ & & \\
\hline \multirow{5}{*}{ Ascorbic acid } & 0.67 & $09.5 \pm 0.12$ & \multirow{5}{*}{2.3} & \multirow{5}{*}{$y=24.4 x-4.44\left(r^{2}=0.954\right)$} \\
\hline & 1.33 & $24.8 \pm 0.36$ & & \\
\hline & 2.00 & $52.5 \pm 0.22$ & & \\
\hline & 2.67 & $63.9 \pm 0.03$ & & \\
\hline & 3.30 & $70.3 \pm 0.01$ & & \\
\hline
\end{tabular}

Results are expressed as means \pm SD of five parallel measurements.

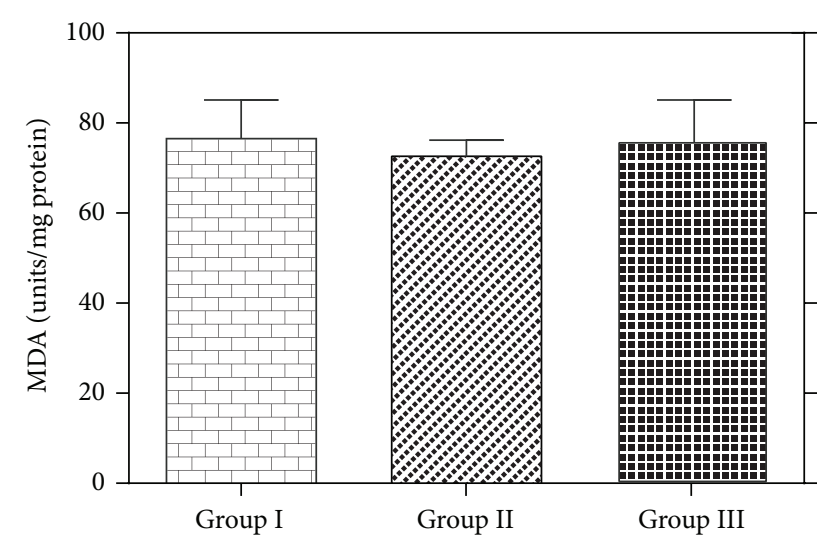

FIGURE 3: Hepatic lipid peroxidation measured as malondialdehyde (MDA) generated in liver homogenates prepared from rats treated with distilled water as control (Group I), $100 \mathrm{mg} / \mathrm{kg}$ (Group II) or $200 \mathrm{mg} / \mathrm{kg}$ (Group III) MLE of G. kola. Data are presented as means $\pm \mathrm{SD}(n=6)$.

circumvent hydroxyl radical induced initiation of membrane lipid peroxidation.

Superoxide anion is a relatively weak oxidant generated in aerobic cells with the ability to transform into more reactive species such as $\mathrm{H}_{2} \mathrm{O}_{2}, \mathrm{OH}^{\bullet}$, and singlet oxygen, which induce oxidative damage in lipids, proteins, and DNA [24], and has been implicated in several pathophysiological processes [25].
The riboflavin/NBT/illumination system generates superoxide anion which reduces the yellow dye $\left(\mathrm{NBT}^{2+}\right)$ to a blue formazan product that can be measured spectrophotometrically at $560 \mathrm{~nm}$. The superoxide anion scavenging property exhibited by $G$. kola may be due to neutralization of $\mathrm{O}_{2}{ }^{-}$ radical via hydrogen release and reduction of NBT by various phytochemical constituents in the extract. The inhibition of superoxide anion by the MLE of G. kola leaf may be of biological significance in terms of the cellular damage attributed to superoxide anion radical.

1,1-Diphenyl-2-picrylhydrazyl radical (DPPH) reacts in the presence of antioxidants to form 1,1-diphenyl-2-picryl hydrazine. The degree of discoloration from deep purple to yellow indicates the extent of radical scavenging potential of the antioxidant [26]. The MLE of G. kola and ascorbic acid exhibited DPPH radical scavenging activities in a concentration-dependent manner. The DPPH scavenging activity of the extract may be due to its ability to donate hydrogen ions to stabilize free radicals. Thus, the hydrogen donating property is central to the neutralization of free radicals that initiate oxidation processes and termination of radical chain reaction [27].

$\mathrm{ABTS}^{\circ+}$ radical reactions involve electron transfer and take place at a faster rate compared with $\mathrm{DPPH}$ radicals. $\mathrm{ABTS}^{\bullet+}$ generation involves direct production of a blue/green chromophore through reaction between ABTS and potassium persulfate to give an absorbance of 0.750 at $734 \mathrm{~nm}$ 


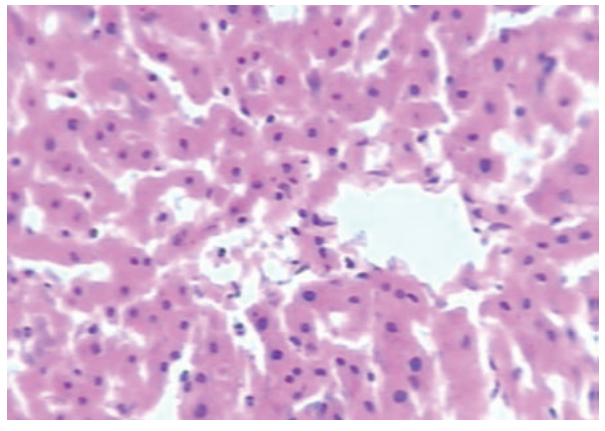

(a)

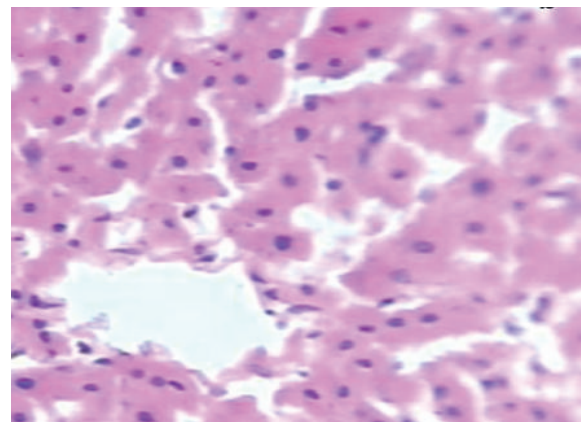

(b)

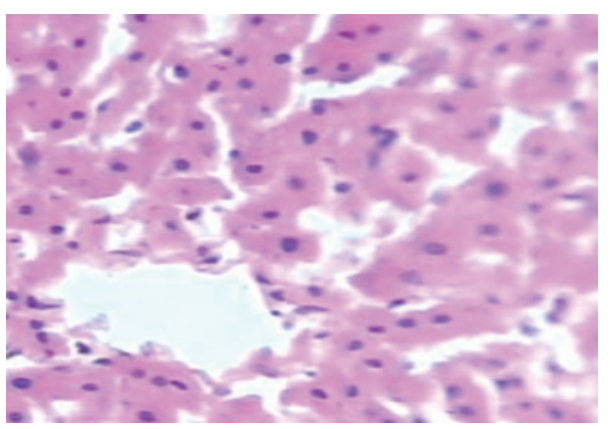

(c)

FIGURE 4: Histopathology of livers from rats in each treatment group. (a) Group I, distilled water control; (b) Group II, $100 \mathrm{mg} / \mathrm{kg}$; and (c) Group III, $200 \mathrm{mg} / \mathrm{kg}$ MLE of G. kola. A portion of liver was fixed in 10\% formalin and embedded in paraffin. Each liver section of $4-\mu \mathrm{m}$ thickness was stained with hematoxylin and eosin for light microscopic assessment at 100x.

TABLE 3: DPPH scavenging activity of the methanolic extract of Garcinia kola and ascorbic acid.

\begin{tabular}{|c|c|c|c|c|}
\hline Sample & Concentration $(\mu \mathrm{g} / \mathrm{mL})$ & \% Inhibition $(n=6)$ & $\mathrm{IC}_{50}(\mu \mathrm{g} / \mathrm{mL})$ & Regression equation \\
\hline \multirow{4}{*}{ Garcinia kola } & 50.0 & $22.60 \pm 0.03$ & \multirow{4}{*}{126.0} & \multirow{4}{*}{$y=0.322 x+9.87\left(r^{2}=0.972\right)$} \\
\hline & 150.0 & $64.30 \pm 0.17$ & & \\
\hline & 200.0 & $75.40 \pm 0.80$ & & \\
\hline & 250.0 & $86.40 \pm 0.06$ & & \\
\hline \multirow{5}{*}{ Ascorbic acid } & 5.0 & $49.20 \pm 0.12$ & \multirow{5}{*}{5.4} & \multirow{5}{*}{$y=1.24 x+43.6\left(r^{2}=0.939\right)$} \\
\hline & 10.0 & $53.90 \pm 0.07$ & & \\
\hline & 15.0 & $66.00 \pm 0.03$ & & \\
\hline & 20.0 & $69.40 \pm 0.07$ & & \\
\hline & 25.0 & $72.40 \pm 0.02$ & & \\
\hline
\end{tabular}

Results are expressed as means \pm SD of five parallel measurements.

TABLE 4: $\mathrm{ABTS}^{++}$scavenging activity of the methanolic extract of Garcinia kola and ascorbic acid.

\begin{tabular}{|c|c|c|c|c|}
\hline Sample & Concentration $(\mu \mathrm{g} / \mathrm{mL})$ & \% Inhibition $(n=6)$ & $\mathrm{IC}_{50}(\mu \mathrm{g} / \mathrm{mL})$ & Regression equation \\
\hline \multirow{5}{*}{ Garcinia kola } & 7.50 & $28.60 \pm 0.08$ & \multirow{5}{*}{34.3} & \multirow{5}{*}{$y=0.653 x+27.7\left(r^{2}=0.929\right)$} \\
\hline & 15.00 & $41.30 \pm 0.07$ & & \\
\hline & 30.00 & $50.60 \pm 0.05$ & & \\
\hline & 45.00 & $52.90 \pm 0.07$ & & \\
\hline & 60.00 & $67.90 \pm 0.04$ & & \\
\hline \multirow{4}{*}{ Ascorbic acid } & 1.50 & $25.20 \pm 0.08$ & \multirow{4}{*}{5.7} & \multirow{4}{*}{$y=6.335 x+14.1\left(r^{2}=0.970\right)$} \\
\hline & 3.75 & $34.10 \pm 0.07$ & & \\
\hline & 6.00 & $55.00 \pm 0.06$ & & \\
\hline & 7.50 & $60.90 \pm 0.08$ & & \\
\hline
\end{tabular}

Results are expressed as means \pm SD of five parallel measurements. 
TABLE 5: Inhibition of lipid peroxidation in egg yolk homogenate by methanolic leaf extract of Garcinia kola and ascorbic acid.

\begin{tabular}{|c|c|c|c|c|}
\hline Sample & Concentration $(\mu \mathrm{g} / \mathrm{mL})$ & \% Inhibition $(n=6)$ & $\mathrm{IC}_{50}(\mu \mathrm{g} / \mathrm{mL})$ & Regression equation \\
\hline \multirow{4}{*}{ Garcinia kola } & 94.24 & $32.90 \pm 0.03$ & \multirow{4}{*}{190.0} & \multirow{4}{*}{$y=0.149 x+21.8\left(r^{2}=0.896\right)$} \\
\hline & 142.86 & $47.10 \pm 0.02$ & & \\
\hline & 190.48 & $51.10 \pm 0.01$ & & \\
\hline & 238.10 & $55.30 \pm 0.02$ & & \\
\hline \multirow{5}{*}{ Ascorbic acid } & 09.50 & $20.60 \pm 0.02$ & \multirow{5}{*}{52.2} & \multirow{5}{*}{$y=0.732 x+11.9\left(r^{2}=0.922\right)$} \\
\hline & 19.00 & $26.10 \pm 0.03$ & & \\
\hline & 28.57 & $31.10 \pm 0.04$ & & \\
\hline & 38.00 & $35.40 \pm 0.04$ & & \\
\hline & 47.62 & $50.80 \pm 0.01$ & & \\
\hline
\end{tabular}

Results are expressed as means \pm SD of five parallel measurements.

TABLE 6: Inhibition of lipid peroxidation in rat liver homogenate by methanolic leaf extract of Garcinia kola and ascorbic acid.

\begin{tabular}{|c|c|c|c|c|}
\hline Sample & Concentration $(\mu \mathrm{g} / \mathrm{mL})$ & \% Inhibition $(n=6)$ & $\mathrm{IC}_{50}(\mu \mathrm{g} / \mathrm{mL})$ & Regression equation \\
\hline \multirow{4}{*}{ Garcinia kola } & 94.24 & $24.00 \pm 0.02$ & \multirow{4}{*}{218.0} & \multirow{4}{*}{$y=0.200 x+6.64\left(r^{2}=0.961\right)$} \\
\hline & 142.86 & $36.00 \pm 0.03$ & & \\
\hline & 190.48 & $48.00 \pm 0.04$ & & \\
\hline & 238.10 & $52.00 \pm 0.06$ & & \\
\hline \multirow{5}{*}{ Ascorbic acid } & 9.50 & $5.40 \pm 0.02$ & \multirow{5}{*}{40.6} & \multirow{5}{*}{$y=1.62 x-15.4\left(r^{2}=0.912\right)$} \\
\hline & 19.00 & $10.60 \pm 0.11$ & & \\
\hline & 28.57 & $32.58 \pm 0.40$ & & \\
\hline & 38.00 & $35.80 \pm 0.05$ & & \\
\hline & 47.62 & $70.00 \pm 0.09$ & & \\
\hline
\end{tabular}

Results are expressed as means \pm SD of five parallel measurements.

in $0.1 \mathrm{M}$ sodium potassium buffer ( $\mathrm{pH} 7.4$ ). The MLE of $G$. kola showed remarkable concentration-dependent inhibition of $\mathrm{ABTS}^{\circ+}$ which shows that the extract can participate in electron transfer, in addition to its $\mathrm{H}$-donating property as found in DPPH radical scavenging.

Malondialdehyde is formed by oxidation of polyunsaturated fatty acids during the lipid peroxidation process and reacts with two molecules of thiobarbituric acid to produce a pinkish red chromogen [28]. This study evaluated the effects of the MLE of G. kola on egg yolk, rat liver and brain homogenates in the presence of $\mathrm{FeSO}_{4}$, a ROS-generating system. The extract showed significant inhibition of lipid peroxidation in all the tissue preparations tested. The inhibition of lipid peroxidation exhibited by the extract, though lower compared to the standard used, could be attributed to the presence of phytochemicals present in the leaves. This implies that the extract has potential to protect the lipid membrane constituents of liver, brain, and egg from $\mathrm{Fe}^{3+}$-induced lipid peroxidation.

The antioxidant properties of vegetables and fruits are significantly correlated with flavonoids, a class of secondary plant phenolics [24]. The flavonoids content of the methanolic extract of $G$. kola leaves in terms of quercetin equivalent was $0.90 \pm 0.07 \mu \mathrm{g} / \mathrm{mg} \mathrm{QE}$ and total phenol was $1.20 \pm$ $0.07 \mu \mathrm{g} / \mathrm{mg}$ GAE. The antioxidant activities observed in this study may relate to the flavonoid and phenolic constituents in the leaf extract.

Hematological parameters are used to assess the effects of xenobiotics such as plant extracts on the well-being of animals [29]. Hematological profiles and biochemical indices are useful and reliable predictive indicators of toxicity in humans [30]. In this study, the plant extract did not show any significant effect on the blood $\mathrm{RBC}, \mathrm{WBC}, \mathrm{PCV}, \mathrm{Hb}$, $\mathrm{MCHC}, \mathrm{MCV}$, and $\mathrm{MCH}$. However, it is remarkable to note that the extract at $100 \mathrm{mg} / \mathrm{kg}$ body weight induced increases in $\mathrm{WBC}$ and decreases with $\mathrm{Hb}$ more than what is observed at $200 \mathrm{mg} / \mathrm{kg}$ extract. Medicinal compounds or drugs have been shown to alter the normal range of hematological parameters either positively or negatively [31, 32].

Plasma AST, ALT, and GGT evaluated in this study show no significant difference in the treated groups compared to the control group. This shows that the MLE at both doses did not induce significant adverse effects on the integrity of hepatic cell membrane. AST, ALT, and GGT are enzymes that are released into circulating blood when the structural integrity of hepatic cells is compromised and therefore are used as biomarkers to evaluate hepatocellular insult [33]. There was a notable decrease in plasma glucose and magnesium in the groups treated with the extract at both concentrations. The decrease observed could be as a result of increased utilization of plasma glucose or enhanced mobilization of the glucose from the plasma to the tissues by the extract. The MLE at $200 \mathrm{mg} / \mathrm{kg}$ induced significant reduction in plasma creatinine while there was no significant effect observed in plasma urea. The observed decrease in creatinine in this study might have been mediated by flavonoids present in the extract. This implies that the leaves can enhance the functional capacity of the kidney. 
TABLE 7: Inhibition of lipid peroxidation in rat brain homogenate by methanolic leaf extract of Garcinia kola and ascorbic acid.

\begin{tabular}{|c|c|c|c|c|}
\hline Sample & Concentration $(\mu \mathrm{g} / \mathrm{mL})$ & \% Inhibition $(n=6)$ & $\mathrm{IC}_{50}(\mu \mathrm{g} / \mathrm{mL})$ & Regression equation \\
\hline \multirow{4}{*}{ Garcinia kola } & 94.24 & $18.0 \pm 0.01$ & \multirow{4}{*}{228.0} & \multirow{4}{*}{$y=0.259 x-8.40\left(r^{2}=0.985\right)$} \\
\hline & 142.86 & $26.0 \pm 0.04$ & & \\
\hline & 190.48 & $42.0 \pm 0.01$ & & \\
\hline & 238.10 & $54.0 \pm 0.03$ & & \\
\hline \multirow{5}{*}{ Ascorbic acid } & 9.50 & $18.0 \pm 0.02$ & \multirow{5}{*}{36.5} & \multirow{5}{*}{$y=1.14 x+8.54\left(r^{2}=0.959\right)$} \\
\hline & 19.00 & $28.0 \pm 0.06$ & & \\
\hline & 28.57 & $47.0 \pm 0.03$ & & \\
\hline & 38.00 & $53.0 \pm 0.01$ & & \\
\hline & 47.62 & $60.0 \pm 0.05$ & & \\
\hline
\end{tabular}

Results are expressed as means \pm SD of five parallel measurements.

TABLE 8: Haematological indices of rat dosed with methanolic leaf extract of Garcinia kola at 100 and $200 \mathrm{mg} / \mathrm{kg}$ for 14 days.

\begin{tabular}{lccccccc}
\hline Groups & RBC $\left(\times 10^{12} / \mathrm{L}\right)$ & WBC $\left(\times 10^{9} / \mathrm{L}\right)$ & PCV $(\mathrm{L} / \mathrm{L})$ & $\mathrm{HB}(\mathrm{g} / \mathrm{L})$ & $\mathrm{MCHC}(\%)$ & $\mathrm{MCV}(\mathrm{fl})$ & $\mathrm{MCH}(\mathrm{pg})$ \\
\hline I & $5.09 \pm 0.31$ & $4.78 \pm 0.65$ & $0.42 \pm 0.05$ & $170.20 \pm 17.98$ & $411.80 \pm 53.80$ & $81.94 \pm 10.04$ & $33.46 \pm 3.07$ \\
II & $5.27 \pm 1.13$ & $6.88 \pm 2.65$ & $0.39 \pm 0.03$ & $151.60 \pm 17.69$ & $393.60 \pm 61.80$ & $73.56 \pm 10.74$ & $30.04 \pm 7.44$ \\
III & $5.43 \pm 0.82$ & $5.45 \pm 1.21$ & $0.40 \pm 0.04$ & $165.75 \pm 15.15$ & $412.00 \pm 22.00$ & $75.58 \pm 14.92$ & $30.95 \pm 4.43$ \\
\hline
\end{tabular}

Data are expressed as mean \pm SD (standard deviation) of six animals in each group. RBC (red blood cell), WBC (white blood cell), PCV (packed cell volume), HB (hemoglobin), MCHC (mean corpuscular hemoglobin concentration), MCV (mean corpuscular volume), and MCH (mean corpuscular hemoglobin). (Group I), $100 \mathrm{mg} / \mathrm{kg}$ (Group II), or $200 \mathrm{mg} / \mathrm{kg}$ (Group III) MLE of G. kola.

TABLE 9: Biochemical indices of rat dosed with methanolic leaf extract of Garcinia kola at 100 and $200 \mathrm{mg} / \mathrm{kg}$ for 14 days.

\begin{tabular}{lccccccc}
\hline Groups & UREA $(\mathrm{mg} / \mathrm{dL})$ & AST $\left(\mathrm{IUL}^{-}\right)$ & ALT $\left(\mathrm{IUL}^{-}\right)$ & $\gamma$-GT $\left(\mathrm{IUL}{ }^{-}\right)$ & Creatinine $(\mathrm{mg} / \mathrm{dL})$ & $\mathrm{GLU}(\mathrm{mg} / \mathrm{dL})$ & $\mathrm{MAG}(\mathrm{mg} / \mathrm{dL})$ \\
\hline I & $44.09 \pm 6.57$ & $27.80 \pm 2.78$ & $22.40 \pm 2.19$ & $4.00 \pm 1.21$ & $3.09 \pm 0.85$ & $40.78 \pm 5.60$ & $2.11 \pm 0.35$ \\
II & $45.13 \pm 3.28$ & $28.00 \pm 3.08$ & $23.20 \pm 9.01$ & $4.17 \pm 1.02$ & $2.46 \pm 1.16$ & $36.09 \pm 2.90$ & $1.73 \pm 0.12$ \\
III & $42.49 \pm 3.76$ & $27.20 \pm 4.09$ & $21.20 \pm 5.22$ & $5.06 \pm 1.31$ & $1.60 \pm 0.77$ & $30.85 \pm 8.60$ & $1.60 \pm 0.02$ \\
\hline
\end{tabular}

Data are expressed as mean \pm SD (standard deviation) of six animals in each group. AST (aspartate transaminase), ALT (alanine transaminase), $\gamma$-GT (gamma glutamyl transpeptidase), GLU (glucose), and MAG (magnesium). (Group I), $100 \mathrm{mg} / \mathrm{kg}$ (Group II), or $200 \mathrm{mg} / \mathrm{kg}$ (Group III) MLE of G. kola.

GSH ( $\gamma$-glutamyl-cysteinyl-glycine or glutathione), a water-soluble tripeptide containing a thiol group, is a potent reducing agent [34]. It has strong antioxidant properties that are essential in the detoxification of a variety of radicals. GSH is used as a cofactor by multiple peroxidase enzymes to detoxify peroxides generated from oxygen radical metabolism [35]. In the present study, the MLE of G. kola significantly $(P<0.05)$ increased hepatic GSH concentration by $13.7 \%$ and $20.1 \%$ at 100 and $200 \mathrm{mg} / \mathrm{kg}$, respectively. Thus, the leaf extract may modulate glutathione metabolism via secondary plant metabolites (bioflavonoids and xanthones).

SOD catalyzes the dismutation of superoxide anion by converting it to hydrogen peroxide [36]. It is the primary catalytic cellular defence that protects cells and tissues against potentially destructive reactions of superoxide radicals and their derivatives. SOD can be induced when cells are exposed to agents that stimulate oxidative stress. The results obtained in this study show that oral administration of the MLE of G. kola did not have a significant effect on the hepatic SOD compared with the control group. This result further suggests that the extract did not cause any increase in superoxide anion that could induce the synthesis or degeneration of SOD.

Glutathione peroxidase (GPx) is a selenoenzyme responsible for the elimination of hydrogen peroxide and singlet oxygen [37]. Significant increases $(P<0.05)$ in GPx activities were observed in rats treated with the extract at 100 and $200 \mathrm{mg} / \mathrm{kg}$ body weight, which shows that the extract at both doses did not adversely affect the activity of GPx. Lipid peroxidation is a chain reaction initiated by free radical through the oxidation of polyunsaturated fatty acid. Malondialdehyde is an accumulated product of peroxidation of long chain fatty acids [38]. Lipid peroxidation in biological systems is one of the major mechanisms of cell injury in aerobic organisms subjected to oxidative stress [39]. Methanolic extracts of $G$. kola at both doses (100 and $200 \mathrm{mg} / \mathrm{kg}$ ) lowered the formation of malondialdehyde in rat liver homogenates compared with the control. This result implies that the leaf extract at both doses maintains hepatic cell integrity.

Histopathological analysis of formalin fixed and paraffinembedded liver sections shows that the extract at both concentrations (100 and $200 \mathrm{mg} / \mathrm{kg}$ ) was well tolerated by the hepatic tissues of rats.

\section{Conclusion}

The in vitro and in vivo effects observed in this study might be linked to the reported phenolic compounds in MLE of G. kola. The mechanisms of the in vitro antioxidant and 
hypoglycaemic effects of the leaf extracts should be studied further in cell culture systems and animal models to enhance our understanding of the physiological significance of our findings and to clarify the usefulness of the G. kola leaves in traditional medicine practices.

\section{Conflict of Interests}

The authors declare that there is no conflict of interests regarding the publication of this paper.

\section{Acknowledgments}

The authors gratefully acknowledge Dr. A. T. J. Ogunkunle for assisting with the identification of $G$. kola leaves used in this study. A special thank is also due to the Head of the Department of Biochemistry, Ladoke Akintola University of Technology, Ogbomosho, Professor A. Aboderin, for granting access to the departmental laboratories to perform some of the assays.

\section{References}

[1] A. J. Modi, S. S. Khadabadi, U. A. Deokate, I. A. Farooqui, S. L. Deore, and M. R. Gangwani, "Argyreia speciosa Linn. f.: phytochemistry, pharmacognosy and pharmacological studies," Journal of Pharmacognosy and Phytotherapy, vol. 2, no. 3, pp. 34-42, 2010.

[2] D. A. Akinpelu, M. F. Adegboye, O. A. Adeloye, and A. I. Okoh, "Biocidal activity of partially purified fractions from methanolic extract of Garcinia kola (Heckel) seeds on bacterial isolates," Biological Research, vol. 41, no. 3, pp. 277-287, 2008.

[3] A. Sofowora, "Recent trends in research into African medicinal plants," Journal of Ethnopharmacology, vol. 38, no. 2-3, pp. 209214, 1993.

[4] J. M. Dalziel, The Useful Plants of West Tropical Africa, 1937.

[5] S. K. Adesina, Z. O. Gbile, O. A. Odukoya, D. D. Akinwusi, H. C. Illoh, and A. A. Jayeola, "Survey of indigenous useful plants of West Africa with special emphasis on medicinal plants and issues associated with management," in The United Nations Programme on Natural Resources in Africa, pp. 84-85, 1995.

[6] K. Terashima, Y. Kondo, M. Aqil, M. Waziri, and M. Niwa, "A study of biflavanones from the stems of Garcinia kola (Guttiferae)," Heterocycles, vol. 50, no. 1, pp. 283-290, 1999.

[7] M. M. Iwu, "Antihepatoxic constituents of Garcinia kola seeds," Experientia, vol. 41, no. 5, pp. 699-700, 1985.

[8] E. O. Farombi, "Mechanisms for the hepatoprotective action of kolaviron: studies on hepatic enzymes, microsomal lipids and lipid peroxidation in carbontetrachloride-treated rats," Pharmacological Research, vol. 42, no. 1, pp. 75-80, 2000.

[9] J. O. Nwankwo, J. G. Tahnteng, and G. O. Emerole, "Inhibition of aflatoxin B1 genotoxicity in human liver-derived HepG2 cells by kolaviron biflavonoids and molecular mechanisms of action," European Journal of Cancer Prevention, vol. 9, no. 5, pp. 351-361, 2000.

[10] D. E. Okwu, "Phytochemicals, vitamins and mineral contents of two Nigeria medicinal plants," International Journal of Molecular Medicine and Advance Sciences, vol. 1, no. 4, pp. 375-381, 2005.
[11] B. Halliwell and M. Grootveld, "The measurement of free radical reactions in humans. Some thoughts for future experimentation," FEBS Letters, vol. 213, no. 1, pp. 9-14, 1987.

[12] C. Beauchamp and I. Fridovich, "Superoxide dismutase: improved assays and an assay applicable to acrylamide gels," Analytical Biochemistry, vol. 44, no. 1, pp. 276-287, 1971.

[13] L. L. Mensor, F. S. Menezes, G. G. Leitao et al., "Screening of Brazilian plant extracts for antioxidant activity by the use of DPPH free radical method," Phytotherapy Research, vol. 15, pp. 127-130, 2001.

[14] R. Re, N. Pellegrini, A. Proteggente, A. Pannala, M. Yang, and C. Rice-Evans, "Antioxidant activity applying an improved ABTS radical cation decolorization assay," Free Radical Biology and Medicine, vol. 26, no. 9-10, pp. 1231-1237, 1999.

[15] G. Ruberto, M. T. Baratta, S. G. Deans, and H. J. D. Dorman, "Antioxidant and antimicrobial activity of Foeniculum vulgare and Crithmum maritimum essential oils," Planta Medica, vol. 66, no. 8, pp. 687-693, 2000.

[16] S. McDonald, P. D. Prenzler, M. Antolovich, and K. Robards, "Phenolic content and antioxidant activity of olive extracts," Food Chemistry, vol. 73, no. 1, pp. 73-84, 2001.

[17] J. Zhishen, T. Mengcheng, and W. Jianming, "The determination of flavonoid contents in mulberry and their scavenging effects on superoxide radicals," Food Chemistry, vol. 64, no. 4, pp. 555$559,1999$.

[18] M. Cheesbrough, District Laboratory Practice in Tropical Countries, Cambridge University Press, Cambridge, Mass, USA, 2000.

[19] E. Beutler, O. Duron, and B. M. Kelly, "Improved method for the determination of blood glutathione," Journal of Laboratory and Clinical Medicine, vol. 61, pp. 882-888, 1963.

[20] H. P. Misra and I. Fridovich, "The role of superoxide anion in the autoxidation of epinephrine and a simple assay for superoxide dismutase., Journal of Biological Chemistry, vol. 247, no. 10, pp. 3170-3175, 1972.

[21] J. T. Rotruck, A. L. Pope, H. E. Ganther, A. B. Swanson, D. G. Hafeman, and W. G. Hoekstra, "Selenium: biochemical role as a component of glatathione peroxidase," Science, vol. 179, no. 4073, pp. 588-590, 1973.

[22] R. Varshney and R. K. Kale, "Effects of calmodulin antagonists on radiation-induced lipid peroxidation in microsomes," International Journal of Radiation Biology, vol. 58, no. 5, pp. 733-743, 1990.

[23] H. Kappus, "Lipid peroxidation-mechanism and biological relevance," in Free Radical and Food Additives, O. I. Aruoma and B. Halliwell, Eds., pp. 59-75, Taylor \& Francis, London, UK, 1999.

[24] P. G. Pietta, "Flavonoids as antioxidants," Journal of Natural Products, vol. 63, no. 7, pp. 1035-1042, 2000.

[25] B. Halliwell and J. M. C. Gutteridge, "Oxygen toxicity, oxygen radicals, transition metals and disease," Biochemical Journal, vol. 219, no. 1, pp. 1-14, 1984.

[26] H. Wang, X. D. Gao, G. C. Zhou, L. Cai, and W. B. Yao, "In vitro and in vivo antioxidant activity of aqueous extract from Choerospondias axillaris fruit," Food Chemistry, vol. 106, no. 3, pp. 888-895, 2008.

[27] G. Cao, E. Sofic, and R. L. Prior, "Antioxidant and prooxidant behavior of flavonoids: structure-activity relationships," Free Radical Biology and Medicine, vol. 22, no. 5, pp. 749-760, 1997.

[28] Y. Kumarasamy, M. Byres, P. J. Cox, M. Jaspars, L. Nahar, and S. D. Sarker, "Screening seeds of some Scottish plants for free 
radical scavenging activity," Phytotherapy Research, vol. 21, no. 7, pp. 615-621, 2007.

[29] M. T. Yakubu, A. M. Akanji, and A. T. Oladiji, "Hematological evaluation in male albino rats following chronic administration of aqueous extract of Fadogia agrestis stem," Pharmacognosy Magazine, vol. 3, pp. 34-38, 2007.

[30] H. Olson, G. Betton, D. Robinson et al., "Concordance of the toxicity of pharmaceuticals in humans and in animals," Regulatory Toxicology and Pharmacology, vol. 32, no. 1, pp. 5667, 2000.

[31] O. P. Ajagbonna, K. I. Onifade, and U. Suleiman, "Haematological and biochemical changes in rats given water extract of Calotropis procera," Sokoto Journal of Veterinary Sciences, vol. 1, no. 1, pp. 36-42, 1999.

[32] M. O. Abatan and R. O. Arowolo, "Toxicity of Eugenia uniflora to rats," Nigerian Journal of Animal Production, vol. 16, pp. 16-19, 1989.

[33] R. Chavda, K. R. Vadalia, and R. 1. Gokani, "Hepatoprotective and antioxidant activity of root bark of Calotropis procera $\mathrm{R} . \mathrm{Br}$ (Asclepediaceae)," International Journal of Pharmacology, vol. 6, no. 6, pp. 937-943, 2010.

[34] D. M. Townsend, K. D. Tew, and H. Tapiero, "The importance of glutathione in human disease," Biomedicine and Pharmacotherapy, vol. 57, no. 3, pp. 145-155, 2003.

[35] R. C. Strange, P. W. Jones, and A. A. Fryer, "Glutathione Stransferase: genetics and role in toxicology," Toxicology Letters, vol. 112-113, pp. 357-363, 2000.

[36] I. Fridovich, "Superoxide anion radical (O2-.), superoxide dismutases, and related matters," Journal of Biological Chemistry, vol. 272, no. 30, pp. 18515-18517, 1997.

[37] M. Erdélyi, M. M. Mézes, and G. Virág, "Selenium dependent glutathione peroxidase in animals. I structure, function regulation," Biokémia, vol. 23, pp. 82-88, 1999 (Hungarian).

[38] C. Ceconi, A. Cargnoni, E. Pasini, E. Condorelli, S. Curello, and R. Ferrari, "Lipid peroxidation during myocardial reperfusion," Molecular and Cellular Biochemistry, vol. 111, no. 1-2, pp. 49-54, 1992.

[39] G. Poli, E. Albano, and M. U. Dianzani, "The role of lipid peroxidation in liver damage," Chemistry and Physics of Lipids, vol. 45, no. 2-4, pp. 117-142, 1987. 

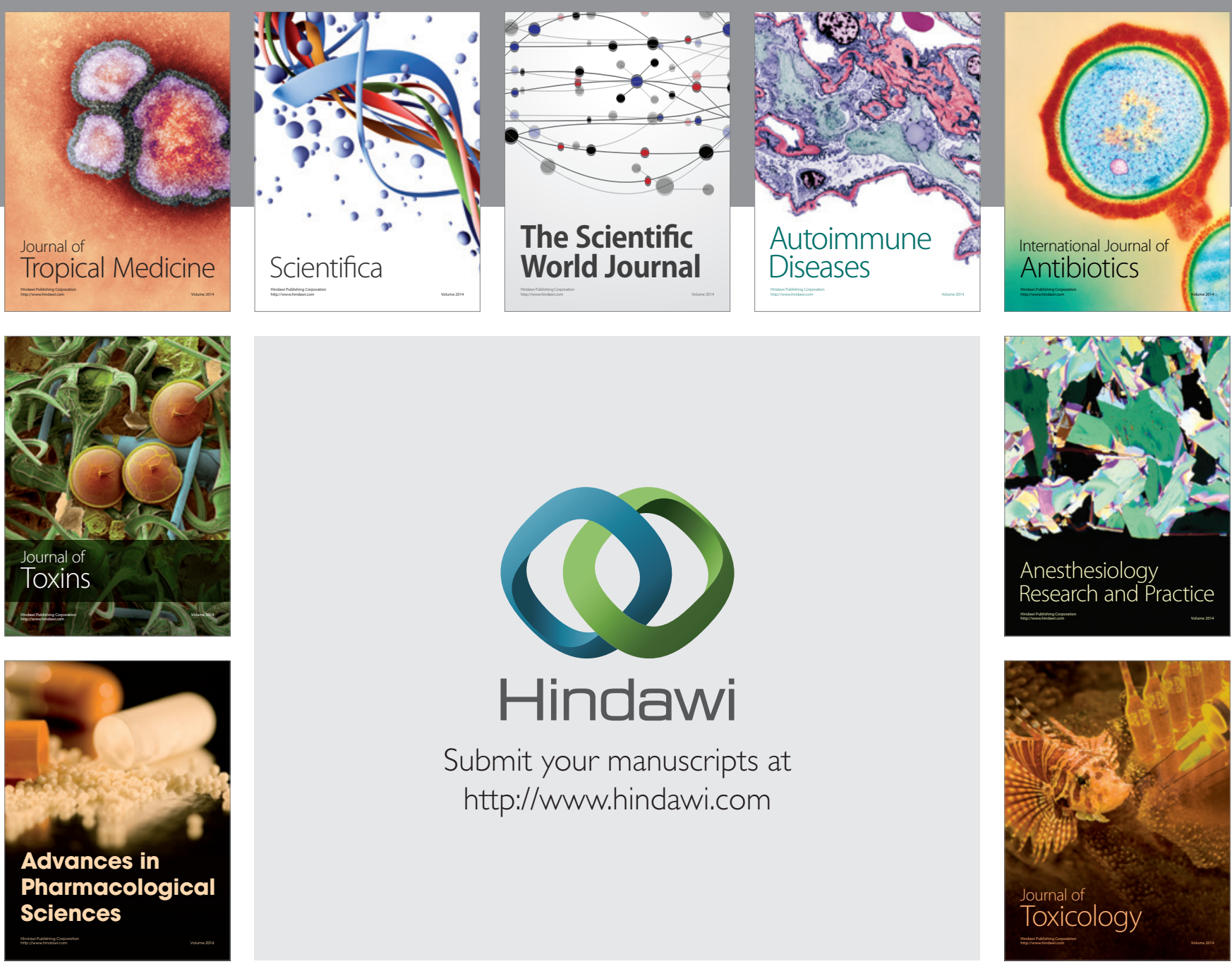

\section{Hindawi}

Submit your manuscripts at

http://www.hindawi.com
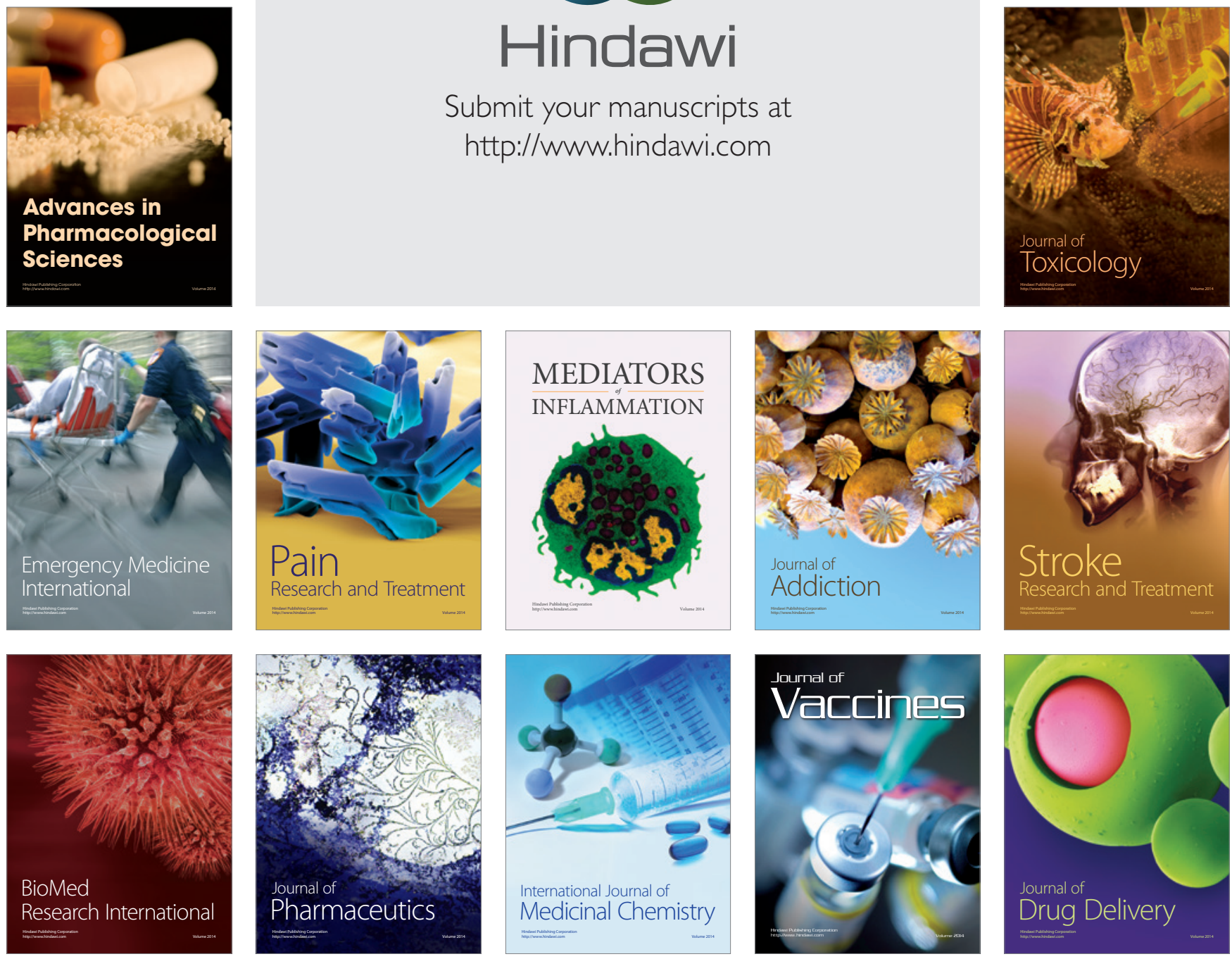